des perspectives de travail améliorées. La Semaine se termine par les exposés sur le développement économique des pays d'outre-mer, et sur les cadres sociaux et l'évolution familiale.

La Semaine Sociale de 1949 se tiendra à Lille du 18 au 23 juillet, et elle aura pour sujet ' Réalisme économique et progrès social '.

\title{
African Studies in Northwestern University, Illinois, U.S.A.
}

THE African research programme, carried on for more than a decade by the Department of Anthropology, Northwestern University, is to be expanded and intensified in the next three years through a programme made possible by a grant of $\$ 30,000$ from the Carnegie Corporation of New York. The programme will be directed towards an understanding of all aspects of contemporary African culture, with particular reference to the changes in native life resulting from the increasing influences of outside forces upon the African.

The training of research personnel for the African area will be a primary objective. Students will be prepared for field study and aided in working up field material, in special seminars to be set up under the leadership of Professor M. J. Herskovits and Dr. W. R. Bascom. The extensive collections of anthropological Africana in Deering Library will be broadened by the acquisition of works dealing with other aspects of the African scene, especially periodicals and government reports. A faculty and advanced graduate interdepartmental seminar will be instituted to provide for an integrated attack on the problems, both scientific and practical, of present-day Africa. It is planned to invite Africanists working in anthropology, economics, education, geography, missions, politics, and public health to discuss before the seminar the aspects of African life falling in their special fields, with the aim of providing Africanist work in other schools and departments of the University.

As an initial step in furthering this programme of African studies, Dr. S. F. Nadel, Reader in Anthropology, King's College, Durham University, England, will lecture at the University during the summer of 1949 on Africanist and related fields.

(Communicated by M. J. Herskovits.)

\section{Committee on Geographical Names (Nairobi)}

THE committee, summoned by the Government of Kenya, and presided over by the Director of Surveys, held its first meeting in Nairobi in November 1948. Mr. Thornley, member for Education, indicated the Government's policy with regard to the difficult question of placenames, to which much thought and discussion had already been devoted by a number of scientific societies. He said that the Government wished the committee to accept two principles which had been adopted in the survey of India, i.e. (I) To adopt all true nativeborn names. (2) To avoid inventing fictitious native names.

In the course of its discussions, the committee dealt at some length with questions of orthography, methods for reproducing the usual native pronunciation of place-names, and the disadvantages of using diacritical marks in the printing of place-names on maps. A resolution was passed approving the use of the customary English spelling for names derived from the English and of the alphabet used for the orthography of Swahili in the case of names derived from the vernaculars used in the country; and recommending that for record purposes and publication in a Gazetteer, the more accurate phonetic pronunciation of the name should be recorded in the alphabet set forth in the document Practical Orthography of African Languages. (Readers are referred to other discussions of this matter, Africa, xviii. I, Pp. 5 I-2 and 4, Pp. 305-6.) 